\title{
Význam členství v online fanouškovské komunitě pro adolescenty
}

\section{Importance of Online Fan Communities for Adolescents}

\author{
Hana Macháčková, Lukáš Blinka
}

\begin{abstract}
The study focused on the importance of membership in online fan communities for adolescents. A subculture of anime and manga was chosen as a typical representative of a marginalized phenomenon. Seventeen interviews were carried out using IM, with 8 women and 9 men aged 16-22. Active online participants as well as so-called lurkers were included. The interviews were analyzed using the grounded theory method. Results identified potential positive outcomes like creating new social contacts and gaining emotional support. However, these social contacts were perceived as inferior in comparison to offline relationships. Generally, participation in fan communities was not strong enough to become a dominant part of adolescent identity.
\end{abstract}

KEYWORDS Adolescence, fan communities, marginalized identity, online identity

\section{Úvod}

Rostoucí význam internetu v naší společnosti rychle podnítil řadu výzkumů poukazujících na pozitivní i negativní vliv takto mediované komunikace. Obavy se týkaly především negativního vlivu na sociální život, emocionální stav a celkově zvyšování odtrženosti od reality (např. Kraut a kol. 1998; Nie, Erbring 2000; Engelberg, Sjöberg 2004). Mezi pozitivní stránky bylo řazeno ulehčení komunikace (Parks, Floyd 1996), zvyšování vnímané sociální podpory (LaRose a kol. 2001) či snižování osamělosti, deprese a zvyšování sebehodnocení (Hamburger, Ben-Artzi 2000; Shaw, Gant 2002; Kraut a kol. 2002).

Jedním z častých témat se stalo zkoumání možného vlivu na jedince, kteří měli určitou část své identity marginalizovanou (např. McKenna, Bargh 1998). Podle Maffesoliho (1996) je typickým znakem postmoderní identity její určitá fragmentace. Identita jedince nabývá podoby mnohočetných identifikací s určitými skupinami, znaky a symboly, které mají emoční a senzualistický ráz. Právě specifický charakter internetu tuto fragmentaci, nebo také experimentaci s identitou, rozvíjí (Turkle 1997). Vznikají zde skupiny a komunity, které přijímají a umožňují vyjadřovat jindy odmítané či nenaplňované části identity (McKenna, Bargh 1998).

Sociální studia. Fakulta sociálních studií Masarykovy univerzity, 2/2009. S. 37-53. ISSN 1214-813X. Studie vznikla s podporou projektů KJB708140702 Grantové agentury Akademie věd a MSM0021622406 Ministerstva školství, mládeže a tělovýchovy ČR. 
Za jednu z marginalizovaných skupin můžeme považovat i subkulturu fanoušků anime a mangy (viz dále). Na jejím konkrétním prrípadu se budeme ptát: Jak ovlivňuje členství ve fanouškovské online komunitě současný život a další vývoj dnešních adolescentů? Jak je propojeno s reálným životem, nakolik tvoří oddělenou část adolescentovy identity a nakolik je tato identita výrazná?

\section{Charakter online komunity}

Ve výzkumu byla za představitele marginalizované skupiny vybrána komunita fanoušků anime a mangy (neboli specifické japonské animované a komiksové tvorby; blíže viz např. Napier 2001), nazývaných otaku. Anime a manga existuje v ČR ve formě subkultury; není u nás kulturně ukotveným ani všeobecně rozšířeným fenoménem, čemuž otaku připisují svá setkání s (různě intenzivním) nepochopením nebo dezinterpretací (běžná veřejnost může mít subkulturu anime spojenou na jedné straně s japonským kresleným pornem, na druhé straně s dětským seriálem Pokémon). Tato komunita proto slouží jako př́klad sociální skupiny, která nemusí nacházet podporu či pochopení v blízkém okolí, jejíž členové ale nejsou výrazněji stigmatizováni, penalizováni či př́mo sociálně vyloučeni.

Významným problémem otaku komunity je relativně malý počet jejích členů. V důsledku malého zastoupení představuje pro otaku primární místo pro setkávání online komunita ${ }^{1}$ a v interakci převládá komunikace prostřednictvím internetu.

Vymezení online komunity je však poněkud problematické - ne všechny stránky, na nichž probíhá interakce, vytvářejí online komunitu (Ridings, Gefen 2004). Pro definici online komunit se tak užívají různá kritéria, střídají se úhly pohledu a je zpochybňována i jejich samotná existence (Belini, Vargas 2003). Např. Jones (1997) vychází z rysů online prostředí: interaktivity, udržitelného členství, diverzity komunikujících a sdíleného virtuálního prostoru (cit. dle Belini, Vargas 2003); Dennis a kol. (1998) ji charakterizují jako „skupinu lidí se společným zájmem či cílem, pro něž je elektronická komunikace primární formou interakce“ (cit. dle Ridings, Gefen 2004 ).

Pro účely práce bude online komunita vymezena pomocí pěti rysů (Belini, Vargas 2003; Porter 2004). Online komunitou zde bude chápáno společenství, pro které platí, že:

1. sociální vztahy jsou vytvářeny v kyberprostoru,

2. vztahy jsou založeny na opakovaném kontaktu,

3. komunita se sdružuje kolem určitého tematického celku,

4. komunita má určité normy a role,

5. větší počet členů prožívá tzv. zážitek virtuální komunity - „pocity členství, identity, náležení a připoutání ke skupině, která primárně interaguje prostřednictvím elektronické komunikace“ (Blanchard 2007: 827).

Přestože se online komunity často zakládají za informativním účelem, „explicitní výměna informací je jen jedním typem interakce ve virtuální komunitě” (Burnett, Buerkle 2004). Ridings a Gefen (2004) určují následující motivy vedoucí k začlenění se do online komu-

Jak uvádí Šmahel (2008), mezi nejčastější návštěvníky online komunit patří právě adolescenti ve věku 16-19 let (51 \%), návštěvnost věkové skupiny 20-26 let dosahuje 31 \%. 
nity: nejčastějším motivem je hledání informací, dále pak hledání sociální podpory (procítěný zájem ostatních členů, instrumentální pomoc, informace či rada) a prátelství a nakonec participace jako druh odpočinku. U adolescentů, pro něž jsou primární vrstevnické vztahy, lze však předpokládat větši důraz na komunikační funkci, s hlavním cílem udržet, rozšśríit či vytvořit nové vztahy s vrstevníky (Subrahmanyam 2007). Ovšem přestože jsou online a offline vztahy některými výzkumy hodnoceny jako podobně významné (McKenna, Bargh 2000; Wolak a kol. 2002), je třeba reflektovat závěry výzkumu provedeného v ČR a poukazujícího na to, že adolescenti častěji vnímají vztahy na internetu jako nereálné a vyhýbají se jejich označení jako „přátelství“ (Šmahel, Konečný 2006), čemuž odpovídá i častá tendence přenést vztah do reálné roviny.

Participace $\mathrm{v}$ online komunitách může nabývat různých podob (obecně můžeme rozlišovat např. hostilní či naopak kolaborativní chování; Burnett, Buerkle 2004) a intenzity. Participaci však ovlivňuje již samotný charakter online komunikace. Ta se vyznačuje několika specifickými rysy, mezi něž patř́ anonymita uživatele, odpoutanost od časoprostorového kontextu (McKenna, Bargh 2000), multiplicita, okamžitost (a současně) výhoda rozmýšlení reakce, možnost porušování norem, dostupnost uživatele, snadný útěk z nepříjemné interakce (vztahu) (Šmahel 2003) či působení disinhibičního efektu, díky němuž dochází k většímu sebeotevření (Suler 2004). Důsledkem online interakce tak může být projevení vnímaného „pravého já“, pocit větší intimity v online vztahu, možnost experimentovat s vlastní identitou či jednoduše umožnění interakce lidem, kteří mají v „offline“ vztazích silné zábrany. Mezi negativní jevy pak patří např. zvýšená hostilita, agresivní vystupování či znemožnění skupinového konsenzu. Specifickým typem chování, které není součástí přímé komunitní interakce, je tzv. lurking (McKenna, Bargh 1998). Tzv. lurkers přitom mohou být nejpočetněǰsí částí komunity, mohou ji navštěvovat stejně často jako aktivní participanti a vytvářet si silné vztahy k těmto aktivním členům (výzkumy naznačují, že i lurkers jsou ovlivněni členstvím v komunitě a mohou si dokonce vytvořit přátelské vztahy k členům, s nimiž nikdy nemluvili; Ridings, Gefen 2004).

\section{Specifika současného utváření identity}

Identita na internetu obecně vytváŕí dojem jakési fluidnosti, mnohosti možných „já“, multiplicity (Turkle 1995, 2005; Gackenbach, Stackelberg 2007). Podobně je definována rovněž adolescence jako období životra, z čehož vyplývá určitá atraktivita internetu právě pro adolescenty, jimž umožňuje snadněji a intenzivněji uchopit svou identitu. Adolescence je často chápána jako klíčové období v procesu utváření identity (Erikson 1994a, b). McAdams a kol. (2006) popisují adolescenci a mladou dospělost jako období rekonstrukce minulé zkušenosti a plánování budoucnosti ve formě budování ucelenější, přesto však multiplicitní narativní identity. Jeho práce se konkrétněji zaměřuje na období pozdní adolescence, přecházející v mladou dospělost. $\mathrm{V}$ tomto období dochází $\mathrm{k}$ diferenciaci obsahu sebepojetí, přičemž „zejména v pozdní adolescenci je diferenciace obsahu současně provázena úsilím o novou integraci“ (Macek 1999: 63), což souvisí s uvědomováním si souvislostí mezi rolemi.

Jak uvádí Macek (1999), pro utváření identity je důležitá sebereflexe, vědomí vlastní stability, well-being, kompetence, sebepojetí a sebehodnocení. Tyto aspekty jsou přitom silně 
ovlivňovány sociálním okolím dospívajícího. „Pro celé období adolescence je charakteristická zvýšená sebereflexe (...), k vlastnímu já jsou vztahovány názory a soudy subjektivně významných osob, vrstevnické standardy a společenské normy“ (Macek 1999: 61). I McAdams a kol. (2006) zdůrazňují, že příběhy tvoříme $\mathrm{v}$ rámci konverzací, které se liší v jednotlivých sociálních situacích a kontextech; různá prostředí také nabízí různé způsoby konstrukce narativ. Vnímaná podpora či pozitivní hodnocení významných druhých jsou důležité pro vlastní sebehodnocení i vědomí vlastní účinnosti, zdatnosti (Robinson 1995, Hall-Lande a kol. 2007), a přestože jsou pro adolescenty po celou dobu velmi důležitými referenčními osobami rodiče, zásadní roli mají také vrstevnické vztahy, jejichž kvalita a blízkost je často integrována do adolescentova sebepojetí (Hall-Lande a kol. 2007).

Role významných sociálních skupin při vývoji identity se však problematizuje v př́ípadě, kdy je adolescent členem marginalizované skupiny. Můžeme očekávat, že toto členství bude hodnoceno do určité míry negativně, otázkou však zůstává, jak členství v jednotlivých skupinách celkově ovlivní vývoj a subjektivní hodnocení vlastní identity.

Proces budování identity pak vyvolává další otázky v souvislosti s vlivem charakteru online prostředí. Pro tuto práci je důležitý především potenciál kyberprostoru jako místa, v němž lze svobodně projevovat a rozvíjet osobnostní stránky, které jindy zůstávají inhibovány. Bargh a kol. (2002) konstatují, že internet je prostředím, jež poskytuje možnost projevit (a sdílet s ostatními) „pravé Já“ uživatele a zdůrazňují jeho potenciál pro odkrytí inhibované identity. Podobně i Šmahel a Konečný zmiňují, že „nový rozměr a nové možnosti získalo především experimentování, což je jedno ze specifik adolescentů směřujících k hledání a dotváření vlastní identity“ (Šmahel, Konečný 2006: 161). Suler (2004) přitom uvádí, že pluralita identit se na internetu ukazuje různými způsoby: můžeme se zde projevit ve větší integraci osobnosti, současně však můžeme prezentovat jen jednu část své identity, at' už reálnou či imaginární.

\section{Výzkumný vzorek, sběr a analýza dat}

Účastníci výzkumu byli vybráni ze seznamu členů na diskuzním fóru, které je součástí největšího a nejnavštěvovanějšího serveru této subkultury http://www.otakuland.cz/2 (dále jen OL). Tento server byl vybrán jednak pro svou oblíbenost a vysokou návštěvnost (což umožnilo zaměřit se na více typů členů komunity), jednak i díky tomu, že umožňoval jednoduchý výběr vzorku dle požadovaných kritérií - všechny informace (včetně frekvence vkládání př́íspěvků) byly uvedeny v osobních profilech členů.

Do výběru byly zahrnuti pouze členové fóra, kteří byli registrováni minimálně 7 měsíců před započetím výzkumu, jejichž poslední přihlášení se datovalo nejvýše týden před započetím výzkumu a kteří měli v profilu uveden věk a kontakt na IM (instant messaging programy jako MSN či ICQ). Z tohoto výběru bylo prostřednictvím zprávy na interní poště fóra osloveno 15 mužů a 15 žen, mezi nimiž byli ve stejném poměru zahrnuti členové s vysokou, střední a malou frekvencí přidávání př́íspěvků. $S$ účastí na výzkumu nakonec souhlasilo 17 participantů, s nimiž byl realizován rozhovor. Výsledný vzorek byl složen z 9 mužů a 8 žen

2 Dne 29. 4. 2008 zde bylo 3797 registrovaných uživatelů; mezi podobné stránky v ČR patří www. manga.cz a www.czsoul-society.net (na Slovensku www.manga.sk). 
ve věkovém rozmezí 16-22 let. Většina participantek a participantů ale spadala do věkové kategorie 17-18 let (více než 20ti let dosáhli jen dva participanti); můžeme proto tvrdit, že se tato práce zaměřuje zejména na období pozdní adolescence. Všichni patří mezi relativně pravidelné návštěvníky komunity, 5 účastníkủ patří mezi členy s vysokou frekvencí vkládání př́ispěvků, 6 jich řadíme do pomyslného středu a 6 pak můžeme řadit mezi lurkery.

Prvotní částí výzkumu bylo poznávání charakteristik sledované fanouškovské komunity. To zahrnovalo seznámení se z určitým vzorkem tvorby, sledování českých i zahraničních stránek, blogů, diskuzí a chatů zaměřených na anime a život otaku a pilotní rozhovor s otaku.

Hlavní výzkumnou technikou byl polostrukturovaný rozhovor probíhající prostřednictvím IM. Online rozhovor byl vybrán proto, že lépe odpovídá charakteru zkoumaného (virtuálního) prostředí a sledovanému kontextu působícímu na identitu při online pobytu. Při použití IM také dochází „k vyvolání disinhibičního efektu a redukci sociální žádoucnosti; to může vést ke zvýšené upř́mnosti (a tudíž vyšší validitě)“ (Wood a kol. 2004: 511). Účastník má možnost odpovídat z pohodlí svého domova bez omezení typických pro normální rozhovor, což umocňuje jevy vyznačující online komunikaci: větší uvolněnost, pokles zábran, redukci stresu z rozhovoru (jako určitého druhu sociální situace) a ztrátu obav ze sebeodhalení (Joinson 2007). Zvětšuje se tak pravděpodobnost získat ke spolupráci i „sociálně ostýchavé“ jedince. Výhodou je samozřejmě i snazší dostupnost a realizace rozhovoru. Na druhou stranu výzkumník „,nemusí znát opravdovou identitu účastníka ani to, zda jsou odpovědi pravdivé“ (Wood a kol. 2004: 515) - jak však tito autoři dodávají, s podobnými problémy se podotýkají i jiné typy průzkumů; rovněž je zde větší možnost chybné interpretace významu odpovědi.

Jednotlivé rozhovory (trvání 1-3 hodiny, rozsah průměrně 13 tisíc znaků) probíhaly v rozmezí jednoho měsíce, vždy na základě domluvy s participantem. Pro analýzu dat byla vybrána metoda zakotvené teorie (Strauss, Corbin 1999). Proces analýzy v této metodě probíhá ve třech fázích, v nichž je vytvářena teorie na základě pozorované reality. Během tzv. otevreného kódování zaznamenáváme výskyt jevů pomocí pojmů. Tato prvotní konceptualizace výroků participantů umožňuje identifikaci a vyjasnění základních prvků tématu.

Tab. č. 1: Př́ílady otevřeného kódování

\begin{tabular}{|l|l|}
\hline Výrok participanta & Zaznamenaný jev \\
\hline $\begin{array}{l}\text { Pro mě pobyt mezi př́teli a rodinou... je pro mě lepší, jelikož } \\
\text { je to př́má konfrontace osob, ne po netu. Raději mám reálné } \\
\text { prostředí, než to virtuální. Prostě mi to připadne přirozenější. } \\
\text { (Josuke) }\end{array}$ & $\begin{array}{l}\text { Preference reálného } \\
\text { kontaktu }\end{array}$ \\
\hline $\begin{array}{l}\text { Ale tady na zapade uz se z toho bohúi přirozenost online } \\
\text { vlna, nebo jen pouhy oznaceni, presto to nektery individua } \\
\text { berou za neco novyho a strasne cool co proste musej byt taky }\end{array}$ \\
$\begin{array}{l}\text { a honi si na tom triko kde muzou, cimz pak uplne drti status } \\
\text { anime a mangy v pohledech verejnosti, ktera tim muze byt } \\
\text { znechucena. (Samuri) }\end{array}$ & $\begin{array}{l}\text { Vymezování nepravých } \\
\text { fanouškủ }\end{array}$ \\
\hline
\end{tabular}


V tzv. axiálním kódování pak takto zaznamenané jevy (pojmy) shrnujeme do užších kategorií, hledáme mezi nimi spojitosti a snažíme se určit jejich dimenze. Př́íklady konceptů a dimenzí tvořících širší kategorie jsou uvedeny níže v tabulce č. 2. V tzv. selektivním kódování se snažíme v kategoriích najít obecné zákonitosti. Striktní rozlišení jednotlivých fází je ale jen teoretické, prakticky se vzájemně prolínají jak významově, tak v procesu analýzy. Po každém rozhovoru tak byly nové informace porovnány s dosavadními výsledky analýzy; kategorie a subkategorie (a chápaný vztah mezi nimi) pak mohly být díky nově nabytým údajům pozměněny, aby přesněji odpovídaly realitě. Závěrečná fáze, selektivní kódování, zůstala v tomto výzkumu nenaplněna. Výsledky jsou prezentovány a většinou i diskutovány na úrovni druhé fáze, axiálního kódování.

\section{Výsledky}

Po provedené analýze dat byl vytvořen analytický model, identifikující základní kategorie a procesy nutné k popisu významu členství v online komunitě. Centrální kategorii význam online otaku komunity pro jejího člena - lze však charakterizovat až po popisu kategorií sociálního charakteru otaku komunity a výraznosti identity. Obě jsou v práci nazírány jako aspekty určující sociální identitu fanouška, která tvoří základní rámec celé analýzy.

Tab. č. 2: Soubor kategorií, subkategorií a prríklady dimenzí

\begin{tabular}{|c|c|c|}
\hline Kategorie & Subkategorie & Příklady konceptů a dimenzí \\
\hline $\begin{array}{l}\text { Charakter otaku } \\
\text { komunity }\end{array}$ & & $\begin{array}{l}\text { Vnímaný status komunity, míra pochopení/ } \\
\text { stereotypizace u okolí, favorizace in-group }\end{array}$ \\
\hline \multirow[t]{2}{*}{$\begin{array}{l}\text { Výraznost } \\
\text { otaku identity }\end{array}$} & $\begin{array}{l}\text { Stabilita } \\
\text { identity }\end{array}$ & $\begin{array}{l}\text { Míra aktivity ve fandomu, preference přetrvání kontaktu } \\
\text { s otaku, chtěné pokračování participace na fandomu }\end{array}$ \\
\hline & $\begin{array}{l}\text { Rozsah } \\
\text { identity }\end{array}$ & $\begin{array}{l}\text { Možnost sdílení fanouškovství přáteli, míra preference } \\
\text { kontaktu s otaku, míra pochopení okolí, oddělování } \\
\text { jednotlivých sociálních skupin a identit }\end{array}$ \\
\hline \multirow[t]{4}{*}{$\begin{array}{l}\text { Význam online } \\
\text { otaku komunity }\end{array}$} & $\begin{array}{l}\text { Vlivy } \\
\text { kyberprostoru }\end{array}$ & $\begin{array}{l}\text { Objektivní: čas trávený online, možnost být online. } \\
\text { Subjektivní: kontrola online komunikace, disinhibice, } \\
\text { sociabilita, regulace frekvence i délky návštěv, } \\
\text { nemožnost kontroly projevu druhých }\end{array}$ \\
\hline & $\begin{array}{l}\text { Charakter } \\
\text { prostředí } \\
\text { online } \\
\text { komunity } \\
\end{array}$ & $\begin{array}{l}\text { Diskurzivní prostředí: přítomnost chtěných informací } \\
\text { a materiálů, komunikace jazykem fandomu. Online } \\
\text { prostředí: dostupnost komunity, aktuálnost informací, } \\
\text { rozmanitost informací i komunikace }\end{array}$ \\
\hline & $\begin{array}{l}\text { Vztahy } \\
\text { v rámci } \\
\text { komunity }\end{array}$ & $\begin{array}{l}\text { Sdílený zájem s ostatními, heterogenita členů komunity, } \\
\text { možnost výběru kontaktu díky dostupnosti informací }\end{array}$ \\
\hline & $\begin{array}{l}\text { Online } \\
\text { fanouškovská } \\
\text { identita }\end{array}$ & $\begin{array}{l}\text { Možnost specifického projevu, komunikace, oddělenost } \\
\text { od jiných skupin, anonymita }\end{array}$ \\
\hline
\end{tabular}




\section{Charakter otaku komunity}

Tato kategorie umožňuje definovat, jak charakter dané komunity ovlivňuje projevy otaku identity jedince. Pod pojmem „otaku identita“ myslíme specificky konkretizovanou sociální dimenzi identity (v sociálněpsychologickém pojetí); tedy tu část sociální identity jedince, která se přímo dotýká otaku komunity. Jako základní subkategorie byly vyčleněny vymezení komunity a určení statusu komunity, které jsou uchopeny ve vztahu k jiným sociálním skupinám.

Téměř u každého účastníka se lišila definice toho, co to vlastně znamená „být otaku“. Při vymezování hranic členské komunity participanti užívali kombinaci několika vlastností vztažených především $\mathrm{k}$ fanouškovské aktivitě. Účastníci se tak zařadili do skupiny popsatelné pouze vztahem ke sdílenému diskurzivnímu poli, které však není jasně definováno. Hranice subjektivně vnímané komunity tak lze považovat za poměrně ambivalentní a fluidní. Slovy respondenta: ${ }^{3}$

otaku beru jako něco, co spojuje A, M, Jhudbu, Jkulturu, J..., J... J.. ${ }^{4}$. člověk co je otaku mi přijde jako fanda všech těchto věcí. (Gyoubu)

Z osobnostních či sociálních charakteristik byla zmiňována především osobní motivace k aktivitě ve fanouškovské komunitě, při níž se projevila tendence k vyčleňování určitých subskupin, které nebyly vnímány jako právoplatné součásti komunity.

vznika dalsi urcita vlna takovych radoby otaku, kteri v tom vidi nejaky novy styl a po shlednuti jednoho anime se povazuji za stred sveta, takovych lidi je hodne a casto zaplavuji ruzna fora svymi nazory nebo tvori „,blogiiisky“ o sobe a o tom jak ,je super byt otaku“, z cehoz se mi dela misty nevolno :D (Jingoro)

Každý z účastníků dále popisoval setkání s (různě intenzivním a častým) projevem stereotypů a předsudků spojených s př́slušností $\mathrm{k}$ anime fandomu ze strany veřejnosti.

Predsudky sou vsude a vzdycky budou patrid do zivota Otaku nebo minimalne nekoho kdo se za to nestydi. (Azuki)

Vnímaný status skupiny se odráží v hodnocení příslušné sociální identity, což vede $\mathrm{k}$ tendencím zlepšovat toto postavení pomocí různých typů strategií. Dochází k favorizaci ingroup, obhajování statusu celé subkultury (a tudíž všech otaku), k subjektivnímu snižování váhy názoru druhé osoby, skrývání vztahu ke komunitě před okolím či k již uvedenému vnímání otaku jako heterogenní skupiny, kdy je určitá subskupina jedinců vyčleněna a jsou jí připsány negativní aspekty spojované se skupinou. Přesto se u každého účastníka lišil pohled na to, nakolik je skupinový status subjektivně vnímaným problémem, který by ovlivňoval fanouškův život.

mno je to spis jen jedna $z$ mych stranek:) ale sem hrdy na to ze jsem otaku a rozhodne se nestydim za to ze koukam na nějaky kresleny pohadky pro deti. (Chikuma)

Výroky respondentů (místo jejichž přezdívek jsou použity pseudonymy) dále uvádíme kurzivou.

Výrok participanta zde odkazuje k anime (A) a manze (M), J pak značí ,japonské“. 
Účastníci sice mluvili o jistých potížích $\mathrm{v}$ sociálním životě, žádný však neuváděl důsledky, které by byly výrazně determinující. Příslušnost $\mathrm{k}$ otaku komunitě tedy většinou nebyla vnímána jako hlavní činitel zásadně ovlivňující společenský život participanta.

\section{Výraznost otaku identity}

Tato kategorie popisuje, nakolik se jedinec i v jiných skupinách projevuje jako otaku a potažmo tedy, nakolik otaku v jistém smyslu je. Vychází z teorie identity, popisující výraznost jako pravděpodobnost definovat situaci způsobem, který povede k projevení této identity (Burke, Stryker 2000). Výraznost identity lze posuzovat na škále odkazující k její slabosti nebo síle (neboli postavení v hierarchii dalších identit). Při výzkumu se vynořily dvě určující vlastnosti výraznosti otaku identity: stabilita a rozsah.

Stabilita odkazuje k tomu, nakolik je otaku identita vnímána jako trvalejší součást účastníkovy osobnosti. Přestože participanti často vášnivě líčili současnou fanouškovskou aktivitu, při zamyšlení nad budoucností zmiňovali především přetrvání kontaktu s jinými otaku, k nimž si vytvořili bližší vztah. Je otázkou, jestli by pouze pokračování vztahu podporovalo i přetrvávání otaku identity, nebo zda by oblast významů vztažených $\mathrm{k}$ anime kultuře postupně vymizela či se transformovala v něco širšího. Proto je u stability důležité zohlednit nejen vztah ke konkrétní komunitě, ale i vyjádření ohledně budoucí participace na fandomu.

Jisté není nic. Prostě když na to nebude čas, tak se dívat nebudu. Nicméně fanouškem asi budu stále, $\mathrm{z}$ toho se už tak snadno nevyvleču. Prostě, co už jsem jednou prožil a co ke mě přilnulo, mě už neopustí, a je jedno, jakou část to u mě zabírá. (Josuke)

Rozsahem je myšlena velikost a počet skupin, v nichž jedinec může projevit otaku identitu; můžeme jej pojímat jako př́činu i důsledek výraznosti identity. Určitým předpokladem je, že vyšší hustota sítě takových vztahů zvyšuje výraznost identity. Každý z uživatelů uvedl, že se v okolí setkává s několika blízkými lidmi, s nimiž může alespoň částečně otaku identitu projevit.

poměrně dost kamarádů už přinejmenším jeden díl anime vidělo (mám dojem, že už zbývá jediná kamarádka). (Ogen)

Jinou situaci však někteří otaku zažívali v počátcích svého fanouškovství, kdy otaku identita přinášela pozitivní emoce jako součást prožitku fanouškovství, a tím byla posilována. Vzhledem k velmi malé možnosti jejího uplatnění (neboli sdílení tohoto nadšení) a díky častějšímu setkávání se s nepochopením však současně paradoxně slábla.

Fanouškovství bylo participanty chápáno jako jeden z více zájmů a otaku komunita jako jedna z více skupin prátel či známých. Otaku identita je tudíž chápána jen jako jedna z více identit, lišící se od ostatních svou výrazností. U skupiny s výraznou sebedefinicí, k jakým patří otaku, vidíme relativní stálost ve volbě chování odpovídající otaku-roli v různých sociálních skupinách. Nedostatek porozumění druhých (či možnosti komunikace s druhými), kteří nesdílejí stejný zájem, pak vede k aktivní snaze o kontakt s dalšími otaku, nejčastěji navazovaný prostřednictvím internetu. 
moji pratele jsou hlavne otaku (...).

proc?

ani nevim muzu se snima bavit o anime ktery mame nejradsi kecame vzdy o japonsku. (Akeginu)

Otaku s méně výraznou otaku identitou mnohem více vnímají hranice jednotlivých skupin a projevy identity přizpůsobují do značné míry kontextu a osobám, s nimiž jsou právě v kontaktu. Své chování však do určité míry přizpůsobují všichni fanoušci, nebot' vnímají výlučnost diskurzivního prostředí komunity, jež je pro další okolí neznámé.

Je jasný, že pred spolužáky z vejšky se clovek nebude bavit napríklad o tom, jaký bishík mi príjde nejpritažlivejší nebo tak XD minimálne proto, že by nevedely, o co jde :)) (Ofuku)

Přestože nikdo z účastníků nepatřil mezi otaku s naprosto dominantní identitou (na prvním místě byl pro participanty vztah s prráteli, s nimiž si rozumí ve více oblastech života), všichni kladli na existenci otaku komunity důraz a přáli si minimálně pokračování vztahů s dalšími otaku. Otaku komunita tak pro participanty představovala velmi významnou (a u některých převažující) součást sociálního života.

\section{Význam online otaku komunity}

Centrální kategorií, na kterou se práce zaměřuje, je význam online fanouškovské komunity pro její členy. Tato kategorie zde bude popsána i prostřednictvím reflexe předchozích dvou kategorií.

\section{1) Intervenující faktory související s pobytem v kyberprostoru}

Mezi důležité aspekty, které do jisté míry působí na charakter všech subkategorií, patří objektivní a subjektivní faktory související s pobytem na internetu.

Objektivními faktory jsou myšleny všechny aspekty související s uživáním internetu; tedy napřr. možnost př́istupu k internetu či čas, který je možno strávit online. Subjektivními faktory jsou charakteristiky uživatele vedoucí k rozdílnému chování a prožívání v kyberprostoru; např. preference typu kontaktu, sociabilita jedince či uživatelská zkušenost. Subjektivní faktory mají vliv na rozdílné hodnocení dvou důležitých charakteristik online interakce: distance a disinhibice. Distance byla často vnímána jako bariéra k vytvoření plnohodnotnějších vztahů; jiní participanti distanci naopak vítali a oceňovali míru kontroly (možnost regulovat frekvenci i délku návštěv, způsob kontaktu, téma rozhovoru a výběr komunikačního partnera; kontrola je však také někdy vnímána jako nedostatečná a projevy nesympatických jedinců, které nemohou být efektivně omezeny, mohou odrazovat účastníka od participace na diskuzi), zachování soukromí a celkově pohodlí, kterou online vztah poskytuje.

tak některé lidi je lepší mít po netu (...) no nevíš jak vypadají :D nevíš že jsou to v reálu docela šílenci. (Kasuga)

za počítačem má člověk čas se rozmyslet co a jak napíše, zatímco v tváŕí v tvář to jde někdy rychle $\wedge \wedge$ (Kagerou) 
Při otázkách na charakter sebeprožívání a sebeprojevu v komunitě byla u některých participantů zjištěna určitá tendence k disinhibovanému chování, jež byla u vlastní osoby hodnocena převážně kladně (snadnost otevření se druhým). Při hodnocení chování jiných však byla někdy považována za příčinu nevhodného (vulgárního a obtěžujícího) chování.

\section{2) Charakter prostředí online komunity}

Charakter pobytu na OtakuLand (OL) se vztahuje ke dvěma důležitým dimenzím sledovaného prostředí.

První je online komunita jako diskurzivní prostředí, zasvěcené předmětu specifického zájmu (anime). Server (diskusní fórum) nabízí informace, materiály a diskuzi pomáhající obohatit a dále posilovat fanouškovskou aktivitu. Umožňuje „mluvit jazykem fandomu“, což je hodnoceno jako velmi př́jemný a osobnostně prínosný zážitek. Oblíbenost komunity jako diskurzivního prostoru přitom poukazuje na silnou tendenci ke kompenzaci nedostatku možnosti sdílení významů a uplatnění otaku identity.

s lidmi na otakulandu můžu mluvit o anime mluvit naprosto v klidu do podrobností a vím že mi rozumí ale s kamarádama kteří o anime moc nevědí se moc na toto téma bavit nedá. (Hyouma)

Druhá př́mo vychází z virtuálního charakteru komunity. V rámci našeho výzkumu se vynořily tři důležité vlastnosti, které posilují tendenci k participaci v OL, nebot' nemají rovnocenný ekvivalent v offline fanouškovských skupinách: dostupnost (neboli možnost zapojit se do komunity „tady a ted“"), aktuálnost informací a rozmanitost (týkající se materiálů i členů komunity). Tyto vlastnosti poukazují na význam komunity jako zdroje informací i sociálního prostředí. Prvotním impulsem k navštívení komunity přitom bylo převážně hledání informací, po určité době se však důležitou stala celá otaku komunita.

no dostala kvůli titulkům a pak už to jelo samo chtěla jsem najít pár lidí a našla hrozně moc lidí :D (Kasuga)

\section{3) Vztahy v rámci komunity}

Tato subkategorie popisuje sociální vztahy a typy interakcí, které participanti spojovali s návštěvami serveru. Komunitní server lze vnímat jako prostředí vytvářené interakcí všech přítomných otaku. Povědomí o OL jako o komunitě bylo u participantů spíše slabé, spojnici mezi členy viděli především ve sdíleném zájmu; přesto však vyjadřovali vůči komunitě alespoň minimální závazek (např. respektováním komunitních norem či nezištnou pomocí novým členům).

Členem komunity jsem se stal proto, že jsem chtěl něco také udělat pro ostatní, ne jen nečinně sedět. Chtěl sem prostě přidat ruku k dílu. (Josuke)

Participanti však většinou trvali na heterogennějším vymezování komunity, což společně s distancí vztahů vnímali jako hlavní překážku v chápání OL jako komunity. Jejich chování tedy neodpovídalo tomu, jak si představovali od pobývání na OL, respektive že některá jejich přání si odporovala. Na jedné straně chtěli participovat na dění komunity více, na druhé straně 
si sami udržovali distanci od ostatních. Docházelo pak k výběrovosti oblíbených kontaktů, která často vedla k utvoření subskupiny, k níž měl účastník bližší vztah.

driv jsem na OL chodil casteji a do diskuzi se zapojoval vice, ted uz to spis jen tak procitam, abych mel prehled, co se zhruba deje, jinak se bavim s otaku, ktere znam. (Jingoro)

Tato tentedence k výběrovosti těch, se kterými „se bavím“, je zjednodušena množstvím informací, které lze o druhé straně vyhledat bez nutnosti jakéhokoli kontaktu. U účastníků převládala snaha $\mathrm{k}$ posilování vztahů prostřednictvím offline kontaktů a dalších komunikačních kanálů. Díky této zesílené interakci pak (i přss vnímané nedostatky online interakce) většina participantů vyjadřovala relativní spokojenost s formou udržování vztahů s dalšími otaku:

no, pokud k tomu [offline kontaktu] mám príležitost, tak me to urcite teší. Ale jelikož to není možné tak casto, tak online komunikace je opravdu super. (Ofuku)

Nalezení nového okruhu známých je často hodnoceno jako největší přínos participace na fandomu. Charakter bližších vztahů v těchto subskupinách je však nahlížen velmi rozmanitě. Přestože se našli účastníci, kteří mluvili o nalezení přátelského vztahu, většina participantů se ve své výpovědi často zdráhala užít označení „,přátelstvi““ pro vztah s otaku na OL.

Jednych (pratele) stretavam osobne a druhych na internete, co je podla mna dost velky rozdiel. (Yakushiji)

\section{4) Online fanouškovská identita}

Projevování otaku identity $\mathrm{v}$ online komunitě a kontakt $\mathrm{s}$ dalšími otaku byl pochopitelně spojován zejména s př́ijemnými pocity, $\mathrm{v}$ důsledku posilujícími výraznost této identity. Způsob projevu však sám závisí na výraznosti identity. U fanoušků s méně a středně výraznou identitou byla ceněna anonymita, oddělenost od ostatních sfér života a možnost pobytu bez tvorby pevnějších závazků. Tito členové zažívali v online komunitě výraznější změnu v chování, spojenou s pozitivním prožitkem plynoucím z nezávazného a do značné míry neomezeného projevu otaku identity, která však nebyla zaznamenána či vnímána členy jiných skupin (pokud neměli znalost znakủ té konkrétní subkultury). Při preferenci setrvávání ve více oddělených skupinách je tak online komunita ideálním prostorem pro uplatnění jedné z možných identit.

U participantů $\mathrm{s}$ vysoce výraznou otaku identitou naproti tomu nebyla reflektována významná změna v porovnání s pobytem v jiných skupinách. I u nich však nacházíme spokojenost $\mathrm{s}$ individuálním př́stupem do komunity a často i s odděleností jednotlivých sfér života.

\section{Diskuze}

Náš výzkum se zaměřil na př́islušnost $\mathrm{k}$ fanouškovské subkultuře $\mathrm{u}$ adolescentů, především pak na popis významu participace v online komunitě. Online komunita fanoušků anime a mangy byla vybrána vzhledem k marginalizovanému statusu sociální identity jejích členů. Při bližším pohledu na zkoumanou identitu je nejdříve třeba reflektovat, že fanouškovství má 
kořeny v personální identitě, jejíž charakter určuje i konečnou podobu participace v komunitě. Význam otaku identity jako sociální identity lze rovněž chápat pouze ve vztahu k dalším identitám, nebot' všichni participanti jsou pochopitelně členy dalších subjektivně významných sociálních skupin, a samozřejmě tak navazovali kontakty i mimo komunitu a mimo online prostředí obecně. Nalezené souvislosti dále nelze prŕmo porovnávat s vlivem pramenícím např. z příslušenství k určitému etniku či třídě, jimiž se zabývá většina studií zaměřená na postavení skupin ve společnosti. Otaku identita není dominantní v hierarchii identit jedince a i její stabilitu je nutno vzhledem $\mathrm{k}$ vývojovému období participantů nutno brát s jistou rezervou. Současně je však třeba zohlednit i zjištění, že „,v adolescenci se myšlená konstrukce chtěných možných já stává klíčový motivačním zdrojem intencionálního sebe-vývoje“" (Pinquart a kol. 2004: 467). Proto se otaku identita, která nyní představuje účastníkovo chtěné já, může díky jeho aktivitě stát trvalejší součástí jeho identity. Členství ve skupině s takto specifickým diskurzivním prostředím se rovněž ve zkoumaném vývojovém období (střední a pozdní adolescence, vynořující se dospělost) podílí na způsobu formulace příběhů vázaných k vlastnímu Já a tvorbě narativní identity (McAdams a kol. 2006).

Výsledky studie je tedy nutno chápat především v kontextu online fanouškovských komunit. Fanouškovská subkultura byla pro výzkum vybrána právě proto, že participace na podobném typu komunity je dnes mnohem častějším jevem; a vzhledem k soudobým společenským procesům se lze domnívat, že takové skupiny či subkultury a identifikace s nimi budou dále prribývat (Maffesoli 1996).

Základním zjištěním výzkumu je poznatek, že intenzitu členství v online komunitě u každého participanta posiluje výraznost marginalizované identity. Děje se tak na základě dvou funkcí, které online fanouškovská komunita nabízí. První z nich je informační funkce, zahrnující nabídku informací a materiálů podporujících vlastní fanouškovskou aktivitu. Již ve výzkumu McKenny a Bargha (1998) byla naznačena souvislost mezi aktivním vystupováním v kyberprostoru a následným přijetím takto aktivní marginalizované identity v životě mimo kyberprostor. Druhou funkcí je funkce sociální. Z tohoto pohledu je již samotný pobyt v online komunitě hodnocen kladně, nebot' komunita je vnímána jako diskurzivní prostor, umožňující uplatnit identitu, která je jindy v různé míře marginalizována. Opět přitom dochází k posílení identity, nebot’ i výrazná identita, jež nemůže být projevována, postupně slábne (Burke, Stryker 2000).

Avšak zatímco informační a diskurzivní funkce byly participanty obecně hodnoceny velmi vysoce, sociální funkce byla popisována jako ne zcela uspokojivá a vztahy navazované na internetu byly označovány jako kvalitativně méněcenné v porovnání s kontakty v reálném světě. Toto pojetí odpovídá zjištěním dalších studií (např. Šmahel, Konečný 2003), přičemž vnímaná méněcennost online kontaktu je dávána do souvislosti především s distancí členů komunity. Navazování kvalitních přátelských vztahů je přitom u adolescentů důležité pro budování pocitu osobní pohody, sociální kompetence a hodnoty sebe sama (self-worth) (HallLande a kol. 2007); jejich absence je naopak popisována jako prríčina negativních jevů, jako je samota, agrese či problémové chování (Hussong 2000).

Při reflexi vztahů v komunitě projevovali participanti tendenci k offline setkáním, která by byla ceněna mnohem více než současná podoba vztahů založená jen na mediované komunikaci, což odpovídá i poznatkům z dalších studií (např. McKenna, Bargh 2000). Setrvávání 
ve virtuální komunitě pak může pramenit $\mathrm{z}$ neochoty ztratit př́ležitost tyto vztahy převést do reality. Za další možný motiv lze ale pokládat i zjištění, že komunity bez kontaktu tvárí $\mathrm{v}$ tvář pravděpodobněji zaniknou; tendence $\mathrm{k}$ navazování bližších vztahů tak může pramenit i z přání udržet komunitu stále aktivní (Belini, Vargas 2003). V tomto ohledu je nutno vrátit se k samotnému chápání zkoumaného společenství jako online komunity. Je otázkou, nakolik ji lze takto definovat vzhledem k slabému zážitku virtuální komunity. Domníváme se však, že jde spíše o problém vymezení hranic této komunity, vedoucí $\mathrm{k}$ vyčleňování přijímaných a odmítaných subskupin, než o její popření jako takové. Zde se ukazuje nevýhoda výběru tak velké a heterogenní komunity - pro další výzkum bychom navrhovali zaměřit se na menší a uzavřenější komunitu, s níž by bylo možno naše výsledky porovnat.

Pokud tedy celkově zhodnotíme vliv členství v online komunitě na další vývoj marginalizované identity adolescentů, nacházíme širší spektrum možných vlivů. Ukazuje se, že prožitek a význam členství v online fanouškovské komunitě odpovídá teoretickým náhledům zdůrazňujícím pluralitu, multiplicitu nebo také fluidnost identity v dnešní společnosti. „Mnoho manifestací multiplicity naší kultury, zahrnujících přijetí online osobnosti, přispívá k obecnému přehodnocování tradičních pojetí identity jako jednoty. Online zkušenosti s ,paralelními životy“ jsou součástí kulturního kontextu, který podporuje nové teoretické smýšlení o multiplicitní osobnosti“ (Turkle 1997: 77).

Pozitiva členství v online komunitě nacházíme především u adolescentů experimentujících s identitou, pro které komunita představuje prostor pro kreativní tvorbu identity (posilovanou zvýšenou disinhibicí v kyberprostoru) bez nutnosti tvorby výraznějších závazků, $\mathrm{a} \mathrm{u}$ jedinců $\mathrm{s}$ vysoce výraznou marginalizovanou identitou, u kterých vedou negativní reakce okolí k výraznému snižování sebehodnocení, jež je návštěvou komunity opět posilováno. Tato skupina se navíc pokouší projevovat svou marginalizovanou identitu i v jiných situacích než jen $\mathrm{v}$ rámci fanouškovské komunity. Má tak větší tendenci $\mathrm{k}$ integraci různých částí své identity, což v tomto prŕpadě členství v online komunitě díky posilování marginalizované identity podporuje. Stejný vliv se však může projevit ovšem také negativně: u jedinců se středně výraznou fanouškovskou identitou dochází $\mathrm{k}$ větší disociaci virtuální a offline identity. I přes popisovaný multiplicitní charakter identity je stále zdůrazňována tendence $\mathrm{k}$ jejímu sjednocování (přestože jde spíše o neustálý proces a nikoli o snahu dosáhnout úplné jednoty; McAdams a kol. 2006). Členství v online komunitě, posilující rozvoj marginalizované identity, pak může přinést potíže s integrací identity; a „neproběhne-li sebevymezení úspěšně (...), vzniká tzv. difúzní identita, tj. vlastně neprítomnost či aktivní odmítání sebe samého jako jedinečného subjektu, odlišného od ostatních" (Macek 1999: 24).

$\mathrm{Na}$ závěr je třeba dodat, že přestože samotné členství v online komunitě může být významným prvkem fanouškova života, není činitelem zásadním nebo determinujícím. Př́slušnost $\mathrm{k}$ online komunitě, vztahy realizované po internetu či cílená konstrukce vlastní identity prostřednictvím výběru specifických skupin však pro většinu respondenti̊ představovaly pevnou a kladně hodnocenou část jejich životů. Přestože jsme se pokusili i o obecné úvahy o vlivu členství v online fanouškovských komunitách, je nutné mít na paměti, že výzkum byl proveden pouze na př́kladu jedné z nich. Výsledky mohly být zároveň zkresleny tím, že se participanti rekrutovali pouze $\mathrm{z}$ jednoho (byt' $\mathrm{v}$ této subkultuře nejvýznamnějšího) 
komunitního serveru. V dalších studiích proto navrhujeme porovnání různých fanouškovských komunit jakož i komparaci rozdílnosti vlivu virtuálního a offline prostředí.

\section{Závěr}

Práce se zabývala zkoumáním charakteru prožitku marginalizované identity ve fanouškovské online komunitě u adolescentů a mladých dospělých. Bylo identifikováno několik kategorií, které je při popisu významu virtuálních komunit nutno zohlednit: intervenující faktory související s pobytem v kyberprostoru, charakter prostředí online komunity, charakter online vztahů a projevy identity online. Z těchto kategorií pak můžeme odvodit důsledky členství v takové komunitě, $v$ prrípadě této práce pak důsledky pro rozvoj identity u adolescentů. Online komunity prokazují potenciál pro flexibilitu a experimentování, který byl předvídán s nástupem internetu (Bargh, McKenna 2000), současně však ukazují i potenciální negativní důsledky plynoucí z přilišné pluralizace identity.

Přestože v této práci bylo naznačeno možné negativní působení členství v online fanouškovské komunitě na vývoj v adolescenci, je vliv online fanouškovské komunity v souvislosti s marginalizovanou identitou hodnocen převážně kladně. Uživateli je dovoleno soustředit se na oblast svého zájmu a sdílet nadšení pro určité kulturní a diskurzivní pole, přitom však dochází k reflexi fiktivního charakteru tohoto světa (především online vztahů) a nedochází ke ztrátě vztahu k reálnému okolí. Určitý vliv zde hraje fakt, že fanouškovská identita není natolik výrazná, aby se stala identitou dominantní. Je ovšem třeba říci, že ne všechny internetové komunity jsou tohoto, tedy tzv. fanouškovského typu. Jiné online komunity (můžeme jmenovat napřr. pro-ana či self-harming komunity) pak určitý negativní potenciál mají (Lusková, Blinka, Šmahel 2008).

\section{Literatura}

BARGH, John A. ; McKENNA, Katelyn Y.A. ; FITZSIMONS, Grainne M. Can You See the Real Me? Activation and Expression the „True Self“" on the Internet. Journal of Social Issues, 2002, roč. 58, č. 1 , s. 33 - 48. ISSN 0022-4537.

BELLINI, Carlo Gabriel Porto ; VARGAS, Lilia Maria. Rationale for Internet-Mediated Communities. Cyberpsychology \& Behavior, 2003, roč. 6, č. 1, s. 3 - 14. ISSN 1094-9313.

BLANCHARD, Anita L. Developing a Sense of Virtual Community Measure. Cyberpsychology \& Behavior, 2007, roč.. 10, č. 6, s. 827 - 830. ISSN 1094-9313.

BURKE, Peter J. ; STRYKER, Sheldon. The Past, Present, and Future of an Identity Theory. Social Psychology Quarterly, 2000, roč. 63, č. 4, s. 284 - 297. ISSN 0190-2725.

BURNETT, Gary ; Buerkle, Harry. Information Exchange in Virtual Communities: A Comparative Study. Journal of Computer-Mediated Communication, 2004, roč. 9, č. 2. [cit. 28.5.2009]. Dostupné z www: <http://jcmc.indiana.edu/vol9/issue2/burnett.html>.

DENNIS, Alan R. ; POOTHERI, Sridar K. ; NATARAJAN, Vijaya L. Lessons from the early adopters of Web groupware. Journal of Management Information Systems, 1998, roč. 14, č. 4, s. 65 - 86. ISSN 0742-1222.

ENGELBERG, Elisabeth ; SJOBERG, Lennart. Internet use, social skills and adjustment. Cyberpsychology \&Behavior, 2004, roč. 7, č. 1, s. 41 - 47. ISSN 1094-9313. 
ERIKSON, Erik H. Identity and the life cycle. 2. vyd. New York : W.W. Norton\& Company, 1994a. 191 s. ISBN 0-39331-132-5.

ERIKSON. Erik H. Identity: Youth and cisis. 2. vyd. New York : W. W. Norton \& Company, $1994 \mathrm{~b}$. 336 s. ISBN 0-39331-144-9.

GACKENBACH, Jayne ; STACKELBERG, Heather. Self Online: Personality and Demographic Implications. In: GACKENBACH, Jayne (ed.). Psychology and the internet: intrapersonal, interpersonal, and transpersonal implications. 2.vyd. Amsterdam, Boston : Elsevier, 2007, s. 55 - 76. ISBN 978-0-12369-425-6.

HALL-LANDE, Jennifer A. et al. Social isolation, psychological health and protective factors in adolescence. Adolescence, 2007, roč. 42, č. 166, s. 265 - 286. ISSN 0001-8449.

HAMBURGER, Yair Amichai ; BEN-ARTZI, E. The relationship between extraversion and neuroticism and the different uses of the Internet. Computers in Human Behavior, 2000, roč. 16, č. 4, s. 441 - 449. ISSN 0747-5632.

HUSSONG, Andrea M. Perceived Peer Context and Adolescent Adjustment. Journal of Research on Adolescence, 2000, roč. 10, č. 4, s. 391 - 415. ISSN 1050-8392.

JOINSON, Adam N. Disinhibition and the Internet. In: GACKENBACH, Jayne (ed.). Psychology and the internet: intrapersonal, interpersonal, and transpersonal implications. 2.vyd. Amsterdam, Boston : Elsevier, 2007, s. 76 - 90. ISBN 978-0-12369-425-6.

JONES, Quentin. Virtual-communities, virtual settlements \& cyber-archaeology: A theoretical outline. Journal of Computer Mediated Communication, 1997, roč. 3, č. 3. [cit. 28.5.2009]. Dostupné z www: $<$ http://jcmc.indiana.edu/vol3/issue3/jones.html $>$.

KRAUT, Robert ; PATTERSON, Michael ; LUNDMARK, Vicki ; KIESLER, Sara ; MUKHOPADHYAY, Tridas ; SCHERLIS, William. Internet paradox: A social technology that reduces social involvement and psychological well-being. American Psychologist, 1998, roč. 53, č. 9, s. 1017 - 1031. ISSN 0003-066X.

KRAUT, Robert ; KIESLER, Sara ; BONEVA, Bonka ; CUMMINGS, Jonathon ; HELGESON, Vicki ; CRAWFORD, Anne. Internet Paradox Revisited. Journal of Social Issues, 2002, roč. 58, č.1, S. 49 - 74. ISSN 0022-4537.

LaROSE, Robert ; EASTIN, Matthew S. ; GREGG, Jennifer. Reformulating the Internet paradox: Social cognitive explanations of Internet use and depression. Journal of online behavior, 2001, roč. 1, č. 2. [cit. 28.5.2009]. Dostupné z www: <http://www.behavior.net/JOB/v1n2/paradox.html>.

LUSKOVÁ, Eva ; BLINKA, Lukáš ; ŠMAHEL, David. Blog jako cesta k porozumění dospívajícím. E-psychologie, 2008, roč. 2, č.3, s. 1 - 15. ISSN 1802-8853.

MACEK, Petr. Adolescence: psychologické a sociálni charakteristiky dospivajících. 1. vyd. Praha : Portál, 1999. 207 s. ISBN 80-7178-348-X.

MAFFESOLI, Michel. The time of the tribes: decline of individualism in mass society. 1. vyd. London : Sage, 1996. 188 s. ISBN 0-80398-474-X.

McADAMS, Dan P. ; JOSSELSON, Ruthellen ; LIEBLICH, Amia. Identity and Story: Creating Self in Narrative. 1. vyd. Washington, DC : American Psychological Association, 2006. 284 s. ISBN 1-59147-356-X.

McKENNA, Katelyn Y.A. ; BARGH, John A. Coming out inte age of the Internet: Identity „demarginalization“ through virtual group participation. Journal of personality and social psychology, 1998, roč. 75, č. 3, s. $681-694$. ISSN 0022-3514.

McKENNA, Katelyn Y.A. ; BARGH, John A. Plan 9 from cyberspace: the implication of the internet for personality and social psychology. Personality and social psychology review, 2000, roč. 4, č. 1, s. 57 - 75. ISSN 1088-8683.

NAPIER, Susan J. Anime from Akira to Princess Mononoke: Experiencing Contemporary Japanese Animation. 1. vyd. New York : Palgrave Macmillan, 2001. 311 s. ISBN 0-31223-862-2. 
NIE, Norman H. ; ERBRING, Lutz. Internet and society: A preliminary report. In COMPAINE, B.N. (eds.). The digital divide: Facing a Crisis or Creating a Myth? Cambridge and London : MIT Press, 2001. ISBN 02625-31933. [cit. 28.5.2009] Dostupné z www: <http://www.stanford.edu/group/ siqss/Press_Release/Preliminary_Report.pdf>.

PARKS, Malcolm R. ; FLOYD, Kory. Making friends in cyberspace. Journal of Communication, 1996, roč. 46, č. 1, s. 80 - 97. ISSN 0021-9916.

PINQUART, Martin, SILBEREISEN, Rainer K., WIESNER Margit. Changes in Discrepancies Between Desired and Present States of Developmental Tasks in Adolescence: A 4-Process Model. Journal of Youth and Adolescence, 2004, roč. 33, č. 6, s. 467 - 477. ISSN 00472891.

PORTER, Constance E. A Typology of Virtual Communities: A Multi-Disciplinary Foundation for Future Research. Journal of Computer-Mediated Communication, 2004, roč. 10, č. 1. [cit. 28.5.2009]. Dostupné z <www: http://jcmc.indiana.edu/vol10/issue1/porter.html

RIDINGS, Catherine M. ; GEFEN, David. Virtual Community Attraction: Why People Hang Out Online. Journal of Computer-Mediated Communication, 2004, roč. 10, č. 1. [cit. 28.5.2009]. Dostupné z www: <http://jcmc.indiana.edu/vol10/issue1/ridings_gefen.html $>$.

ROBINSON, Nancy. Evaluating the Nature of Perceived Support and Its Relation to Perceived SelfWorth in Adolescents. Journal of Research on Adolescence, 1995, roč. 5, č. 2, s. $253-280$. ISSN 1050-8392.

SHAW, Linsday H. ; GANT, Larry M. In Defense of the Internet: The Relationship between Internet Communication and Depression, Loneliness, Self-Esteem, and Perceived Social Support. Cyberpsychology \& Behavior, 2002, roč. 5, č. 2, s. 157 - 171. ISSN 1094-9313.

STRAUSS, Anselm L. ; CORBIN, Juliet. Základy kvalitativniho výzkumu: postupy a techniky metody zakotvené teorie. 1. vyd. Boskovice : Albert, 1999. 196 s. ISBN 80-8583-460-X.

SUBRAHMANYAM, Kaveri. Adolescent online communication: Old issues, new intensities. Cyberpsychology: Journal of psychosicial research on cyberspace, 2007, roč. 1, č. 1. ISSN 1802-7962.

SULER, John. The online disinhibition effect. Cyberpsychology \& behavior, 2004, roč. 7, č. 3, s. 321 - 326 . ISSN 1094-9313.

ŠMAHEL, David. Adolescenti a internet: identita, vztahy, komunikace. Brno : Masarykova univerzita, 2003. 198 s. [Disertační práce na Fakultě sociálních studií Masarykovy univerzity na katedře psychologie].

ŠMAHEL, David. Attending onlinecommunities: Culture of youth? In SUDWEEKS, F., ESS, C., HRACHOVEC, H. Cultural attitudes towards technology and communication,. Murdoch, Australia : Murdoch University, 2008, s. 446 - 451. ISBN 978-0-86905-948-7.

ŠMAHEL, David ; KONEČNÝ, Štěpán. Vztahy na internetu: Fantazie i zklamání. In MACEK, P., LACINOVÁ, L. (eds.). Vztahy v dospívání. 1. vyd. Brno : Barrister \& Principal, 2006, s.161 - 175. ISBN 80-7364-034-1.

TURKLE, Sherry. Life on the screen: identity in the age of the Internet. 1. vyd. New York : Simon \& Schuster, 1995. 347 s. ISBN 0-68480-353-4.

TURKLE, Sherry. Multiple Subjectivity and Virtual Community at the End of the Freudian Century. Sociological Inquiry, 1997, roč. 67, č.1, s. 72 - 84. [cit. 28.5.2009]. Dostupné z www: <http://web. mit.edu/sturkle/www/pdfsforstwebpage/ST_Multiple\%20Subjectivity.pdf $>$.

TURKLE, Sherry. The second self: Computers and the human spirit. 1. vyd. Cambridge, Mass : MIT Press, 2005. 372 s. ISBN 0-26270-111-1.

WOLAK, Janis ; MITCHELL, Kimberly J. ; FINKELHOR, David. Close online relationships in a national sample of adolescents. Adolescence, 2002, roč. 37, č. 147, s. 441 - 455. ISSN 0001-8449.

WOOD, Richard T. A. ; GRIFFITHS, Mark D. ; EATOUGH, Virginia. Online Data Collection from Video Game Players: Methodological Issues. Cyberpsychology \& Behavior, 2004, roč. 7, č. 5, s. 511 - 518. ISSN 1094-9313. 


\section{Autorka a autor}

Hana Macháčková je studentkou magisterského stupně oboru psychologie na Fakultě sociálních studií Masarykovy university. Výzkumně se zabývá se problematikou online subkultur a komunit, v současnosti pak zejména weblogy.

Kontakt:110415@mail.muni.cz

Lukáš Blinka pracuje jako výzkumný pracovník v Institutu výzkumu dětí, mládeže a rodiny na Fakultě sociálních studií Masarykovy univerzity. Zabývá se vlivem internetu na jedince i společnost, zejména na děti, adolescenty a mladé dospělé.

Kontakt: blinka@fss.muni.cz 